Original Research

\title{
Stability of a Fe-Rich Cathode Catalyst in an Anion Exchange Membrane Fuel Cell
}

Lin Xie ${ }^{*}$, Donald Kirk

Chemical Engineering \& Applied Chemistry, University of Toronto, Toronto, Canada; E-Mails: lk.xie@mail.utoronto.ca; don.kirk@utoronto.ca

* Correspondence: Lin Xie; E-Mail: Ik.xie@mail.utoronto.ca

Academic Editor: Narendra Kumar

Special Issue: Application of Catalysts in Development of Green Process Technology

Catalysis Research

2021, volume 1 , issue 3

doi:10.21926/cr.2103003
Received: June 09, 2021

Accepted: September 07, 2021

Published: September 16, 2021

\begin{abstract}
Fe-rich alloys have been widely studied as catalyst materials for the cathodic oxygen reduction reaction (ORR) in hydrogen fuel cells, and many have shown high activities. The stability of Ferich catalysts has also been researched, and some studies have shown promising results using an accelerated stress test (AST), which uses a potential cycling method. However, for commercial fuel cell applications, such as standby power systems, the catalyst has to tolerate a high potential for a long period, which can not be represented by the AST test. In this paper, the cathode stability of a Fe-rich catalyst was studied using a standby cell potential of $0.9 \mathrm{~V}, \mathrm{a}$ potential shown to be challenging for the competing Pt catalysts. After $1500 \mathrm{hrs}$ of testing, significant morphology changes of both the tested cathode and anode were found due to a Fe leaching process. Other alloy materials, including $\mathrm{Ni}, \mathrm{Cr}$, and $\mathrm{Mn}$, were also found leached out along with the Fe species from the catalyst framework. The results are a cautionary note for using Fe based catalysts for AEMFC cathodes.
\end{abstract}

\section{Keywords}

Fe; AEMFC; cathode

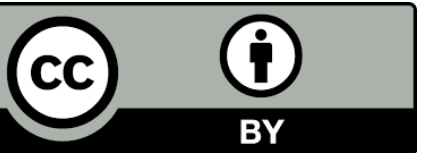

(C) 2021 by the author. This is an open access article distributed under the conditions of the Creative Commons by Attribution License, which permits unrestricted use, distribution, and reproduction in any medium or format, provided the original work is correctly cited. 


\section{Introduction}

Hydrogen gas is a clean energy storage material. Hydrogen fuel cells convert the chemical energy stored in hydrogen gas into electricity [1]. The first fuel cell was developed with an alkaline medium in 1932 [2], and it was applied later as part of the spaceship power system in the Apollo project [1]. However, in recent decades, the fuel cell technology of choice is the acidic proton exchange membrane fuel cell (PEMFC), which uses platinum group metal (PGM) catalysts [3]. Due to the high reliance of PEMFCs on PGM catalysts, there is concern that the limited supply of PGM materials could limit the development of fuel cell production. On the other hand, an alkaline membrane medium in anion exchange membrane fuel cells (AEMFCs) allows non-PGM catalysts to be used. Many AEMFC studies using Fe-Rich catalysts have reported promising cell performances [4-7].

In particular Fe-Rich catalysts have been developed to catalyze the cathodic oxygen reduction reaction (ORR). A typical catalyst system is the Fe-N-C (iron supported by nitrogen-doped carbon substrates) framework. The Fe-N-C structure provides active $\mathrm{FeN}_{\mathrm{x}}$ sites for the ORR process [8-10]. As reported by Serov al., a Fe-N-C cathode was developed using carbendazim (CBDZ) and silica template and achieved $120 \mathrm{~mA} / \mathrm{cm}^{2}$ current density at $0.8 \mathrm{~V} \mathrm{[10].} \mathrm{Another} \mathrm{study} \mathrm{by} \mathrm{Chen} \mathrm{et} \mathrm{al.}$ exhibited an AEMFC using a Fe-N-C ( $\mathrm{SiO}_{2}$ template) cathode, which showed a $230 \mathrm{~mA} / \mathrm{cm}^{2}$ current density with a $100 \mathrm{~mW} / \mathrm{cm}^{2}$ cell power density [11]. Electrospinning polyacrylonitrile (PAN) with a carbon nanofiber framework, a Fe-PAN cathode AEMFC showed a power density of $289 \mathrm{~mW} / \mathrm{cm}^{2}$, $82 \%$ of a Pt/C cathode performance, as reported by Moonste et al. [4]. Also, many other Fe composite catalysts have been reported. Sibul et al. reported a Fe graphene oxide supported catalyst, Fe-N-GO, resulting in an ORR performance of $125 \mathrm{~mA} / \mathrm{cm}^{2}$ current density at $0.8 \mathrm{~V}$ and 243 $\mathrm{mV} / \mathrm{cm}^{2}$ power density [12]. Another Fe graphene catalyst was tested and reported by Yang et al., and the result showed a $30 \mathrm{mV}$ reduction in the cathodic overpotential compared to a $20 \mathrm{wt} \% \mathrm{Pt} / \mathrm{C}$ catalyst [13]. As reported by Miller et al., an AEMFC with a Fe/C cathode achieved $1 \mathrm{~W} / \mathrm{cm}^{2}$ peak power density at $60^{\circ} \mathrm{C}$, with a current density of $0.7 \mathrm{~A} / \mathrm{cm}^{2}$ [14]. Miller et al. further improved that structure by alloying with $\mathrm{Co}$ [15]. Another FeCo/C catalyst was developed by Lilloja et al. with a mesoporous structure, and the high surface area helped achieve a cathodic performance equivalent to $\mathrm{Pt} / \mathrm{C}$ [16]. Moreover, Fe was also used as an alloy component in many fuel cell catalyst systems, including Pt-Fe/C, Ni-Cu-Fe, and FeMn [17-19]. By using the Fe-N-C composite as the substrate of $\mathrm{Pt}$, Qiao et al. developed a Pt/FeN ${ }_{4}-\mathrm{C}$ catalyst, which achieved an $824 \mathrm{~mW} / \mathrm{cm}^{2}$ power density at $0.67 \mathrm{~V}$ [20]. The PtFe composite catalyst activity retained $80 \%$ of its initial value after 30000 cycles of testing at between $0.6 \mathrm{~V}$ and $0.9 \mathrm{~V}$ [20]. A similar Pt/Fe-N-C catalyst structure was adopted by Xie et al. in an acidic fuel cell environment [21]. The results showed a high cathodic performance, $0.46 \mathrm{~A} / \mathrm{mg}_{\mathrm{Pt}}$, in terms of the amount of the Pt used, compared to $0.19 \mathrm{~A} / \mathrm{mg}_{\mathrm{Pt}}$ of the commercial Pt/C catalyst [20]. Another PtFe composite catalyst was developed by Mayorova et al., using a heterometallic carboxylate complex structure, showing an ORR activity of $20 \%$ over the conventional $\mathrm{Pt} / \mathrm{C}$ catalyst [22]. Mari et al. reported a flower-like Pd iron oxide graphitic carbon nitride supported catalyst (g-C3N4/Fe2O3/PdNPs), and the composite structure was found highly effective for the ORR process [23].

For an operating AEMFC cathode, the local environment consists of high moisture, high potential, and concentrated oxygen gas [1]. Under such a corrosive environment, though Fe-Rich catalysts have exhibited high, close to PGM activities, catalyst stability should be considered vitally important. Shin et al. identified a stability issue from the ORR process on the typical Fe-N-C structure [24]. The 
study suggested that $\mathrm{H}_{2} \mathrm{O}_{2}$, a side product of the ORR process, can oxidize the Fe component, and the electrode performance could be passivated due to the coverage of $\mathrm{FeO}_{\mathrm{x}}$ on the catalytical sites [24]. Some stability testing has been reported for a Fe-N-C (CBDZ template) catalyst, which showed an activity decrease of $6 \%$ after 10000 potential cycles in an oxygen environment [10]. A Fe-N-C $\left(\mathrm{SiO}_{2}\right)$ catalyst was also tested in an AEMFC, showing a $4.65 \%$ performance drop at $0.6 \mathrm{~V}$ cell potential over $60 \mathrm{hrs}$ [11]. However, performance stability studies have some limitations. The reported performance losses reflected the deactivation of the catalyst but not necessarily the loss of the catalyst into the electrolyte. For the first study, the samples were tested using cyclic potentials. While the cycling potential method does age the catalyst, any dissolved species could replate locally during the cycling and thus not detect catalyst contamination of the cell.

In real practices such as fuel cell backup power systems, the catalysts are operated at a high constant potential for a certain long period. The constant potential allows dissolved catalyst material to migrate far from the cathode, potentially entering the membrane or even reaching the anode. A steady-state potential test can be more severe than a cyclic potential test when catalyst dissolution is slow. The second reported test provided an operating AEMFC environment, but the period, 60 hours at $0.6 \mathrm{~V}$, is short compared to required commercial operating times [11]. A higher cell potential of $0.9 \mathrm{~V}$ for a longer time frame would be a more realistic test of stability [25-27]. The work we present is not on catalytic activity loss but the chemical stability of the catalyst components in an alkaline environment under a cathodic potential field. The electrochemical dissolution of iron could lead to compromising membrane and anode functionality in an operating fuel cell. Our previous work on the chemical stability of $\mathrm{Ni}$ and $\mathrm{Pt}$ in cathode catalysts using a $0.9 \mathrm{~V}$ cell potential for 1500 hrs showed that both $\mathrm{Ni}$ and Pt could migrate through an AEM and deposit at the surface of the anode [28]. In this work, we studied the chemical stability of an Fe-Rich catalyst under the steady-state conditions of $0.9 \mathrm{~V}$ for a 1500 hour test.

An Fe-Rich catalyst, which is under development, was provided to us for a chemical, not catalytic stability analysis. The base alloy, having a stainless steel type composition contained $\mathrm{Fe}, \mathrm{Ni}, \mathrm{Cr}$, and $\mathrm{Mn}$ was believed to be immune to the alkaline conditions. The catalytic elements were not disclosed nor included in this base alloy. We supported the alloy powder on a carbon support and used this as a cathode in an operating AEMFC structure for $1500 \mathrm{hrs}$. The goal was to determine whether the base alloy would be chemically stable under these conditions. SEM analysis was used to track element migration. The results are important for cathode catalyst development using Fe as an alloy or composite component.

\section{Experimental}

\subsection{Materials}

Methanol (99.5\% Fisher Scientific $\left.{ }^{\circledR}\right)$, sodium hydroxide ( $\mathrm{NaOH} 98.8 \%$ Fisher Scientific $\left.{ }^{\circledR}\right)$, deionized water (18Mohm, Milli-Q ${ }^{\circledR}$ ), Vulcan ${ }^{\circledR}$ X72 carbon nanoparticles (Cabot Corporation ${ }^{\circledR}$ ), FAA3-50 (Fumatech ${ }^{\circledR}$ ), 10\% FAA-3-10 ionomer solution(Fumatech ${ }^{\circledR}$ ), Sigracet ${ }^{\circledR}$ 29BC carbon papers, hydrogen gas $\left(99.9999 \%\right.$ Linde $\left.^{\circledR}\right)$ and oxygen gas (99.999\% Linde $\left.{ }^{\circledR}\right)$, Fe-Rich catalyst powder was used for testing 


\subsection{Catalyst Composition Analysis}

To analyze the Fe-rich catalyst composition, $0.12 \pm 0.04 \mathrm{~g}$ samples were digested using $25 \mathrm{~g}$ of aqua regia. A $200^{\circ} \mathrm{C}, 2$ bar microwave digestion process was applied for 30 mins. The digested samples were analyzed using ICP-AES.

\subsection{Catalyst Ink and Catalyst Coated Membranes}

Vulcan ${ }^{\circledR} \mathrm{X} 72$ (XC72 carbons) and Fe-Rich powders were used to specifically prepare the ink for the anode and cathode. To prepare $100 \mathrm{~g}$ catalyst ink, a $64 \mathrm{mg}$ catalyst powder (Fe-Rich catalyst $\sim 20 \mathrm{~nm}$ or XC72 carbons $\sim 50 \mathrm{~nm}$ diameter) was mixed with $210 \mathrm{mg}$ of $10 \%$ FAA-3-10 ${ }^{\circledR}$ ionomer and $25 \mathrm{~g}$ DI water. Methanol was added to reach 100g, and the solution was then sonicated. After $2 \mathrm{hrs}$ of ice-bathed sonication at $50 \mathrm{~Hz}$ with a Cole-Parmer ${ }^{\circledR} 8857$ sonicator, a catalyst ink suspension was formed. Stirring was then applied for 48 hours.

The prepared catalyst inks were air-spray coated on an FAA-3-50 Fumatech ${ }^{\circledR}$ AEM $(50 \mu m$ thickness). The ink (XC72 carbons or Fe-Rich powder) was sprayed gently on a $2.5 \mathrm{~cm}^{*} 2.5 \mathrm{~cm}$ electrode area (framed by a PTFE mask) to achieve a $0.78 \mathrm{mg} \mathrm{cm}^{-2}$ catalyst loading. The load was measured by weight gain. After each coating, the sample was dried in an oven $\left(\sim 60^{\circ} \mathrm{C}\right)$ for $12 \mathrm{hrs}$.

The CCMs were then alkaline exchanged. Each CCM sample was immersed in $50 \mathrm{~mL}$ of $0.2 \mathrm{M}$ $\mathrm{NaOH}$ solution. The alkaline solution was replenished on a daily basis. $\mathrm{A} \mathrm{Br}$ - selective electrode was used to determine each replenished solution's released $\mathrm{Br}$ - ion concentration. When no $\mathrm{Br}$ - could be detected, the converted samples were washed and rinsed with DI water until the droplets from the samples showed no alkalinity with a phenolphthalein indicator $(\mathrm{pH}<9)$. For comparison, additional unused XC72 and Fe-Rich CCM samples were prepared and alkaline treated by the same method.

\subsection{Membrane Electrode Assembly and Cell Assembly}

The AEMFC environment was simulated by a test cell structure derived from our previous work on catalyst chemical stability [28], shown in Figure 1. In this structure, the XC72 CCM was used at the anode as CCM a. The Fe-Rich CCM was used the cathode (CCM c). An additional AEM layer (b) was placed in between the CCMs. For this work, the third layer was not required since the anode contained none of the cathode alloy elements. The three layers were then sandwiched by Sigracet ${ }^{\circledR}$ 29BC carbon GDLs and the endplates from the Heliocentris's Dr. FuelCell Take-Apart Fuel Cell. As the anode was not catalyzed in this setup, any detection of the cathodic catalyst elements in the center or anodic side membrane demonstrates migration from the cathode catalyst. 


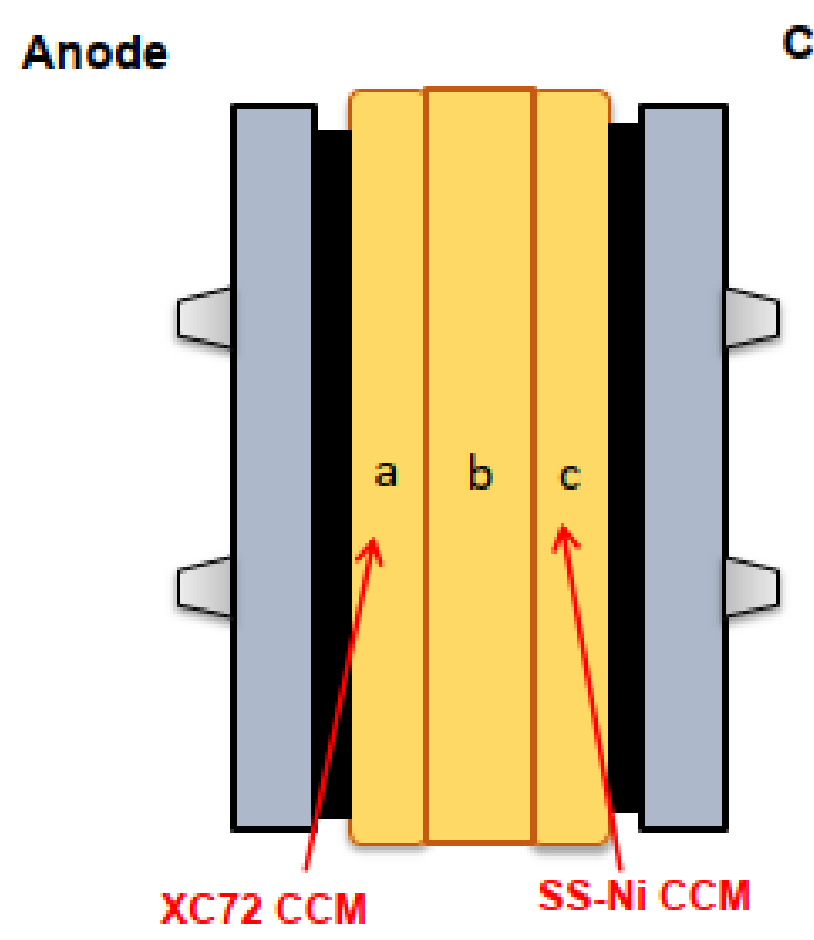

Figure 1 Schematic of the test cell structure with three layers of AEM assembly structure Note, to show the cross section of the AEMS, the drawings are not to scale [28].

\subsection{Chemical Stability Test Operation:}

After the cell was assembled, hydrogen gas (99.999\% Linde $\left.{ }^{\circledR}\right)$ was fed to the anode at $3 \mathrm{ml} \mathrm{min}^{-}$ 1 , and oxygen gas (99.999\% Linde ${ }^{\circledR}$ ) was fed to the cathode at $1.5 \mathrm{ml} \mathrm{min}^{-1}$. The oxygen gas was humidified by bubbling through DI water to avoid membrane drying. The test cell operating temperature was controlled at $60 \pm 3{ }^{\circ} \mathrm{C}$, which is within the conventional AEMFC test range of 55$75^{\circ} \mathrm{C}$ [29-32], using a heating tape surrounding the cell. The whole-cell assembly was tested at a steady-state voltage of $0.9 \mathrm{~V}$, which has been used in other fuel cell stability studies [25, 27, 33]. A (Metrohm Autolab ${ }^{\circledR}$ ) potentiostat with a $48 \mathrm{k}$ ohm load was used to maintain the voltage. The resulting current flow density was approximately constant at $3 \mu \mathrm{A} / \mathrm{cm}^{-2}$ over the test period. The voltage simulates the standby mode of a fuel cell stack. The temperature, voltage, and gas flows were monitored and kept constant throughout the test. After 1500hrs operation ( 2 months), a time which has been used in other fuel cell stability studies $[25,33,34]$, the cell was dissembled for analyses.

\subsection{SEM Analysis}

SEM analysis was conducted using a Hitachi ${ }^{\circledR}$ SU-5000 SEM, which was equipped with secondary electron (SE), back-scattering electron (BSE), and energy-dispersive X-ray (EDX) modes to identify any material morphology change and migration within the MEA. SEM crosssection samples and untested samples were prepared by following the procedure described in supporting document S3. 


\section{Results and Discussions}

\subsection{Catalysis Composition}

The composition of the Fe-rich catalyst was analyzed using ICP-AES, and the composition is shown in Table 1. The measured ICP signals are provided in supporting document S4. The compositions of SS $304 \& 316$ are used for comparison.

Table 1 The chemical composition of the Ni alloy catalyst, SS304, and SS316.

\begin{tabular}{llll}
\hline wt\% & Sample & SS304 (range) [35] & SS316 (range) [36] \\
\hline $\mathrm{Fe}$ & $65.1 \pm 0.6$ & $67.5-71.5$ & $63-72$ \\
$\mathrm{Ni}$ & $14.5 \pm 0.2$ & $8-10.5$ & $10-14$ \\
$\mathrm{Cr}$ & $17.3 \pm 0.1$ & $17.5-19.5$ & $16-18$ \\
$\mathrm{Mn}$ & $0.42 \pm 0.01$ & $0-2$ & $0-2$ \\
\hline
\end{tabular}

As shown in Table 1, the Fe rich catalyst contains Fe (65.1 wt\%), $\mathrm{Ni}(14.5 \mathrm{wt} \%), \mathrm{Cr}(17.3 \mathrm{wt} \%)$, and $\mathrm{Mn}(0.42 \mathrm{wt} \%)$. The catalyst has a composition similar to two stainless steel materials (SS304 \&316) provided for reference in Table 1.

\subsection{Cathode Analysis}

SEM analysis was conducted on an unused Fe-Rich catalyst and on a sample from the AEMFC fuel call test. Figure $2 a$ shows the SEM imaging on the untested sample surface, and Figure $2 b$ shows the imaging on the tested cathode. A EDX scan was used to collect chemical composition information, and the results are included in Figure $2 c$ (untested) \& Figure $2 d$ (tested).

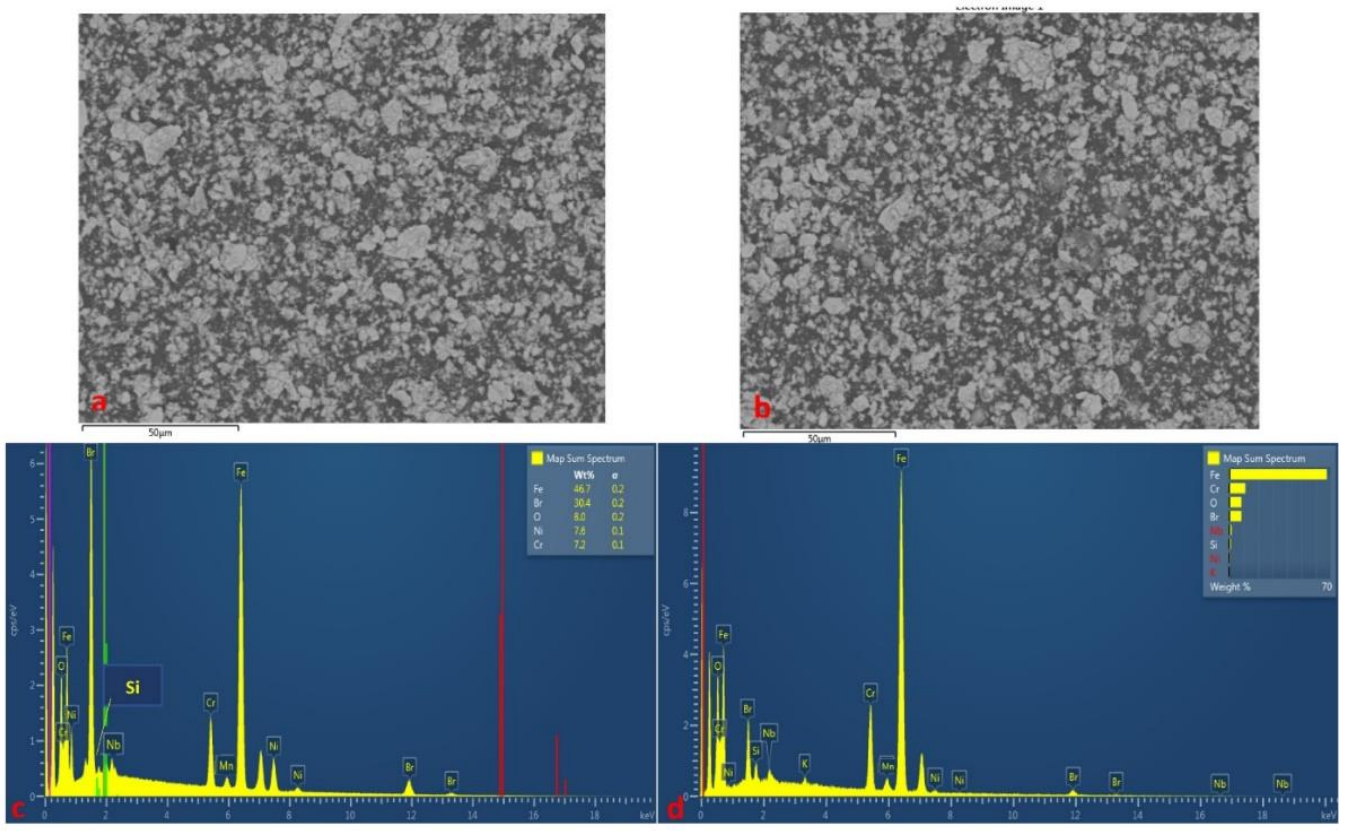

Figure 2 SEM images of a) untested Fe-Rich catalyst b) catalyst tested at the cathode;

c) EDX result of a), d) EDX result of $b$ ). 
As shown in Figure 2a, the untested catalyst particles can be seen as bright flakes on the dark AEM background. The flakes have sizes ranging from $\sim 1 \mathrm{~nm}$ to $\sim 20 \mathrm{~nm}$ in diameter. The average flake diameter from Figure 2a (untested) was $5.2 \mathrm{~nm}$ using an ImageJ program. After $1500 \mathrm{hrs}$ of the stability test, the Fe-Rich particles (bright) are still seen in a flake shape, but fewer large flakes can be found, as shown in Figure $2 \mathrm{~b}$. The average diameter after the test (Figure 2b) was $3.8 \mathrm{~nm}$, suggesting a significant material loss during the AEMFC test.

The EDX scanning results from the untested sample (Figure 2c) show multiple metal signals, including $\mathrm{Fe}, \mathrm{Ni}, \mathrm{Mn}, \mathrm{Cr}$, consistent with the previous ICP result. Some non-metal signals were also identified because the analyzed sample was coated on an AEM layer. The $\mathrm{Br}$ and Si signals came from the FAA-3-10 ionomer as the catalyst binder; the $C$ and $O$ are basic elements of the AEM polymer structure. After 1500 hrs of the stability test, the EDX scanning results (Figure $2 \mathrm{~d}$ ) show similar elemental signals, including $\mathrm{Fe}, \mathrm{Ni}, \mathrm{Mn}, \mathrm{Cr}, \mathrm{C}, \mathrm{O}, \mathrm{Si}, \mathrm{Br}$. An additional $\mathrm{K}$ signal can be seen from the $\mathrm{KOH}$ used for the AEM alkaline exchange. The $\mathrm{Ni}$ signal is quite weak compared to the one scanned from the untested sample (Figure 2c). Using EDX surface analysis of the cathode, the metal losses are $72.3 \mathrm{wt} \% \mathrm{Fe}, 91.2 \mathrm{wt} \% \mathrm{Ni}, 53.4 \mathrm{wt} \% \mathrm{Cr}$, and $83.8 \mathrm{wt} \% \mathrm{Mn}$ relative to the original alloy. The very low remaining surface concentration of $\mathrm{Ni}$ suggests preferential leaching.

\subsection{Anode Analysis}

SEM analysis was conducted on the untested XC72 carbon layer and the anode from the test. Figure 3a shows the SEM image on the untested sample surface, and Figure $3 \mathrm{~b}$ shows the image on the anode. EDX analysis was used to collect chemical information, and the results are shown in Figure 3c (untested) and Figure 3d anode.
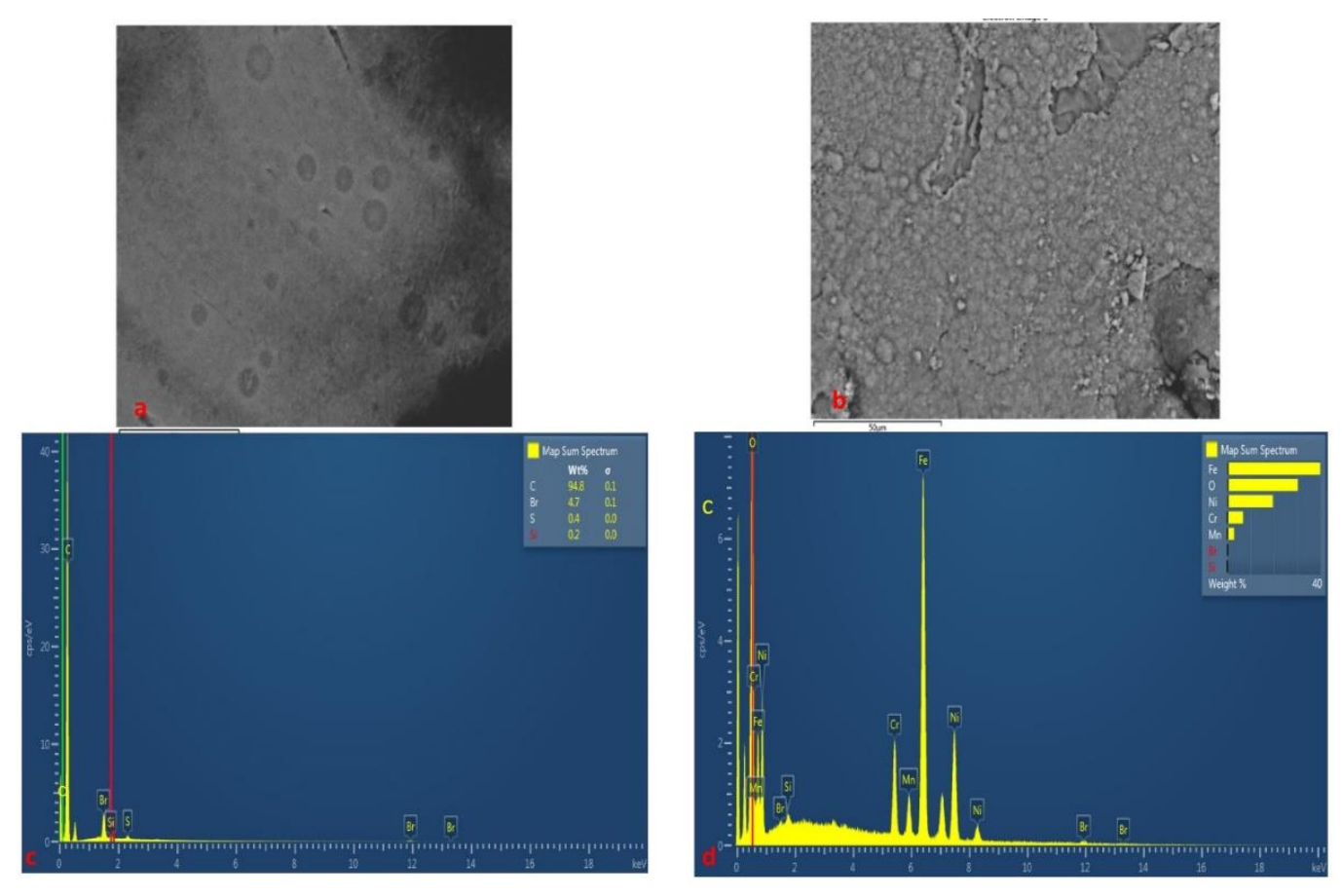

Figure 3 a) SEM imaging showing the surface of an untested XC72 layer coated on an AEM b) SEM imaging showing the surface of an anodic tested XC72 layer; c) SEM-EDX spectrum showing the chemical components of a), d) SEM-EDX showing the chemical components of $b$ ). 
As shown in Figure 3a, an untested XC72 layer's surface comprises a dark background and distributed white species. Some circular marks can be seen, which could be from the ink spraying process. In Figure 3b, the topology of the anodic XC72 layer surface after the test is shown using SEM-SE imaging. A bright layer can be seen covering the XC72 carbon surface.

EDX analysis was used to study and compare the composition of the two surfaces. As shown in Figure $3 \mathrm{c}$, the untested $\mathrm{XC72}$ surface is composed of $\mathrm{C}, \mathrm{O}, \mathrm{Br}, \mathrm{Si}, \mathrm{S}$ elements. The carbon signal was from the XC72 particles, and the $\mathrm{O}, \mathrm{Br}, \mathrm{Si}$, and $\mathrm{S}$ signals were from the $\mathrm{FAA}-3-10$ ionomer (catalyst binder). No metal species were detected.

After the test, the anode still showed $\mathrm{C}, \mathrm{O}$, and Si (Figure 3b), consistent with the untested material (Figure $3 \mathrm{c}$ ) but now has $\mathrm{Fe}, \mathrm{Ni}, \mathrm{Cr}$, and $\mathrm{Mn}$. The metal signals were strong, suggesting a concentrated layer on the surface of the anode. Using EDX surface analysis of the anode, the anodic deposition included $65.8 \mathrm{wt} \% \mathrm{Fe}, 21.4 \mathrm{wt} \% \mathrm{Ni}, 15.3 \mathrm{wt} \% \mathrm{Cr}$, and $7.6 \mathrm{wt} \% \mathrm{Mn}$. Also, the $\mathrm{O}$ signal is much stronger than the untested sample, indicating that the migrated species are in oxidized forms.

As the detected metal elements are components of the cathodic catalyst, the results demonstrate that catalyst components were dissolved and migrated from the Fe-Rich cathode catalyst to the un-catalyzed anode surface. The result suggests that the loss of $\mathrm{Ni}$ is more significant than the other components, which is suspected to be caused by Ni dissolution $\left(\mathrm{Ni}(\mathrm{OH})_{3}^{-}\right)$, migration, and deposition $\left(\mathrm{Ni}(\mathrm{OH})_{2}\right.$ ) process, as reported by earlier research of the authors [28]. Also, the result has shown a significant oxidation of the Fe component. As indicated by Shin et al., the iron oxidation was suggested to be caused by $\mathrm{H}_{2} \mathrm{O}_{2}$, a by-product from the ORR process. Oxidation products can cover the catalytical sites, leading to deactivation of the electrode performance [24].

\section{Conclusions}

An Fe-Rich cathode catalyst (Fe 71.7wt\%, Cr 10.2 wt\%, Ni 7.8wt\%, Mn 0.4\%) was the subject of a stability study of an AEMFC held at $0.9 \mathrm{~V}$ for $1500 \mathrm{hrs}$. All of the species were found to be solubilized and migrate through a thick AEM. After the test, the un-catalyzed anode electrode was found with deposited $\mathrm{Fe}, \mathrm{Cr}, \mathrm{Ni}$, and $\mathrm{Mn}$ species that had migrated from the cathodic catalyst. There appeared to be enhanced Ni migration compared to other elements since the concentration at the anode was elevated. Iron rich catalyst degradation through dissolution and migration is a significant concern for iron based anodic catalysts in AEM FCs.

\section{Acknowledgments}

This research was conducted as part of the Engineered Nickel Catalysts for Electrochemical Clean Energy project administered from Queen's University and supported by Grant No. RGPNM 4779632015 under the Natural Sciences and Engineering Research Council of Canada (NSERC) Discovery Frontiers Program.

\section{Author Contributions}

Professor Kirk designed the experimental work and Dr Xie carried out the measurements. Both contributed to the analysis of the results. 


\section{Competing Interests}

The authors have declared that no competing interests exist.

\section{References}

1. EG\&G Technical Services, Inc. Fuel Cell Handbook. 7th ed. Morgantown: U.S. Department of Energy; 2004.

2. Bacon FT. The fuel cell: Some thoughts and recollections. J Electrochem Soc. 1979; 126: 7C.

3. Hamnett A. In: Handbook of Fuel Cells-Fundamentals, Technology and Applications. Hoboken: John Wiley \& Sons, Inc.; 2003. pp.1-28.

4. Mooste M, Kibena-Põldsepp E, Vassiljeva V, Kikas A, Käärik M, Kozlova J, et al. Electrospun polyacrylonitrile-derived Co or Fe containing nanofibre catalysts for oxygen reduction reaction at the alkaline membrane fuel cell cathode. ChemCatChem. 2020; 12: 4568-4581.

5. Jaouen F, Goellner V, Lefèvre M, Herranz J, Proietti E, Dodelet JP. Oxygen reduction activities compared in rotating-disk electrode and proton exchange membrane fuel cells for highly active FeNC catalysts. Electrochim Acta. 2013; 87: 619-628.

6. Otsuji K, Yokota N, Tryk DA, Kakinuma K, Miyatake K, Uchida M. Performance hysteresis phenomena of anion exchange membrane fuel cells using an Fe-N-C cathode catalyst and an inhouse-developed polymer electrolyte. J Power Sources. 2021; 487: 229407.

7. Wang YC, Lai YJ, Song L, Zhou ZY, Liu JG, Wang Q, et al. S-doping of an Fe/N/C ORR catalyst for polymer electrolyte membrane fuel cells with high power density. Angew Chem. 2015; 54: 99079910.

8. Mineva T, Matanovic I, Atanassov P, Sougrati MT, Stievano L, Clémancey M, et al. Understanding active sites in pyrolyzed Fe-N-C catalysts for fuel cell cathodes by bridging density functional theory calculations and 57Fe Mossbauer spectroscopy. ACS Catal. 2019; 9: 9359-9371.

9. Szakacs $C E$, Lefèvre $M, K r a m m ~ U I$, Dodelet JP, Vidal F. A density functional theory study of catalytic sites for oxygen reduction in $\mathrm{Fe} / \mathrm{N} / \mathrm{C}$ catalysts used in $\mathrm{H}_{2} / \mathrm{O}_{2}$ fuel cells. Phys Chem Chem Phys. 2014; 16: 13654-13661.

10. Serov A, Artyushkova K, Atanassov P. Fe-N-C oxygen reduction fuel cell catalyst derived from carbendazim: Synthesis, structure, and reactivity. Adv Energy Mater. 2014; 4: 1301735.

11. Chen L, Xing $Y$, Cai S, Wang R, Li S, Li J, et al. Ordered iron-and nitrogen-doped carbon framework as a carbon monoxide-tolerant alkaline anion-exchange membrane fuel cell catalyst. Energy Technol. 2018; 6: 1003-1010.

12. Sibul R, Kibena-Põldsepp E, Ratso $S$, Kook M, Sougrati MT, Käärik M, et al. Iron-and nitrogendoped graphene-based catalysts for fuel cell applications. ChemElectroChem. 2020; 7: 17391747.

13. Yang D, Li Y, Han G. Single-atom Fe-NG as an efficient electrocatalyst for oxygen reduction reaction. J Electroanal Chem. 2021; 892: 115271.

14. Miller HA, Pagliaro MV, Bellini M, Bartoli F, Wang L, Salam I, et al. Integration of a Pd-CeO $\mathrm{C}_{2} / \mathrm{C}$ anode with Pt and Pt-free cathode catalysts in high power density anion exchange membrane fuel cells. ACS Appl Energy Mater. 2020; 3: 10209-10214.

15. Ipadeola AK, Lisa Mathebula NZ, Pagliaro MV, Miller HA, Vizza F, Davies V, et al. unmasking the latent passivating roles of $\mathrm{Ni}(\mathrm{OH})_{2}$ on the performance of Pd-Ni electrocatalysts for alkaline ethanol fuel cells. ACS Appl Energy Mater. 2020; 3: 8786-8802. 
16. Lilloja J, Mooste M, Kibena-Põldsepp E, Sarapuu A, Zulevi B, Kikas A, et al. Mesoporous ironnitrogen co-doped carbon material as cathode catalyst for the anion exchange membrane fuel cell. J Power Sources Adv. 2021; 8: 100052.

17. Guo X, Jia J, Dong H, Wang Q, Xu T, Fu B, et al. Hydrothermal synthesis of FeMn bimetallic nanocatalysts as high-efficiency cathode catalysts for microbial fuel cells. J Power Sources. 2019; 414: 444-452.

18. Hua B, Li M, Luo JL, Pu J, Chi B, Li J. Carbon-resistant Ni- $\mathrm{Zr}_{0.92} \mathrm{Y}_{0.08} \mathrm{O}_{2-\delta}$ supported solid oxide fuel cells using $\mathrm{Ni}$-Cu-Fe alloy cermet as on-cell reforming catalyst and mixed methane-steam as fuel. J Power Sources. 2016; 303: 340-346.

19. Li W, Xin Q, Yan Y. Nanostructured Pt-Fe/C cathode catalysts for direct methanol fuel cell: The effect of catalyst composition. Int J Hydrog Energy. 2010; 35: 2530-2538.

20. Qiao Z, Wang C, Li C, Zeng Y, Hwang S, Li B, et al. Atomically dispersed single iron sites for promoting $\mathrm{Pt}$ and $\mathrm{Pt}_{3} \mathrm{Co}$ fuel cell catalysts: Performance and durability improvements. Energy Environ Sci. 2021. Doi: 10.1039/D1EE01675J.

21. Xie L, Kirk DW. Stability comparison of Pt and $\mathrm{Ni}$ as base metal catalysts in anion exchange membrane fuel cells. J Electrochem Soc. 2020; 167: 064519.

22. Mayorova NA, Modestov AD, Grinberg VA, Shiryaev AA, Shapovalov SS, Nickolsky MS, et al. Nanoscale catalyst based on a heterometallic carboxylate complex of platinum and iron for hydrogen-air fuel cells. Mater Chem Phys. 2021; 259: 123968.

23. Mari E, Tsai PC, Eswaran M, Ponnusamy VK. Efficient electro-catalytic oxidation of ethylene glycol using flower-like graphitic carbon nitride/iron oxide/palladium nanocomposite for fuel cell application. Fuel. 2020; 280: 118646.

24. Shin D, Bhandari S, Tesch MF, Bonke SA, Jaouen F, Chabbra S, et al. Reduced formation of peroxide and radical species stabilises iron-based hybrid catalysts in polymer electrolyte membrane fuel cells. J Energy Chem. 2022; 65: 433-438.

25. Ferreira PJ, Shao-Horn Y, Morgan D, Makharia R, Kocha S, Gasteiger HA. Instability of Pt/C electrocatalysts in proton exchange membrane fuel cells: A mechanistic investigation. J Electrochem Soc. 2005; 152: A2256-A2271.

26. Kim L, Chung CG, Sung YW, Chung JS. Dissolution and migration of platinum after long-term operation of a polymer electrolyte fuel cell under various conditions. J Power Sources. 2008; 183: 524-532.

27. Helmly S, Eslamibidgoli MJ, Friedrich KA, Eikerling MH. Local impact of Pt nanodeposits on ionomer decomposition in polymer electrolyte membranes. Electrocatalysis. 2017; 8: 501-508.

28. Xie L, Kirk DW. Nickel catalyst migration in an anion exchange membrane fuel cell. Electrochim Acta. 2020; 364: 137091.

29. Lu W, Zhang G, Li J, Hao J, Wei F, Li W, et al. Polybenzimidazole-crosslinked poly (vinylbenzyl chloride) with quaternary 1, 4-diazabicyclo (2.2.2) octane groups as high-performance anion exchange membrane for fuel cells. J Power Sources. 2015; 296: 204-214.

30. Li N, Leng $\mathrm{Y}$, Hickner MA, Wang CY. Highly stable, anion conductive, comb-shaped copolymers for alkaline fuel cells. J Am Chem Soc. 2013; 135: 10124-10133.

31. Gao X, Yu H, Jia J, Hao J, Xie F, Chi J, et al. High performance anion exchange ionomer for anion exchange membrane fuel cells. RSC Adv. 2017; 7: 19153-19161.

32. Zhao Y, Yu H, Yang D, Li J, Shao Z, Yi B. High-performance alkaline fuel cells using crosslinked composite anion exchange membrane. J Power Sources. 2013; 221: 247-251. 
33. Cherevko S, Kulyk N, Mayrhofer KJ. Durability of platinum-based fuel cell electrocatalysts: Dissolution of bulk and nanoscale platinum. Nano Energy. 2016; 29: 275-298.

34. Zhang J, Litteer BA, Gu W, Liu H, Gasteiger HA. Effect of hydrogen and oxygen partial pressure on Pt precipitation within the membrane of PEMFCs. J Electrochem Soc. 2007; 154: B1006B1011.

35. AZO Materials. Stainless Steel-Grade 304 (UNS S30400) [Internet]. Manchester: AZO Materials; 2019 [cited date 2020 November 23rd]. Available from: https://www.azom.com/article.aspx?ArticlelD=965.

36. AZO Materials. Stainless Steel-Grade 316 (UNS S31600) [Internet]. Manchester: AZO Materials; [cited date 2020 November 23rd]. Available from: https://www.azom.com/article.aspx?ArticlelD=863.

37. Xie NH, Zhang $\mathrm{M}, \mathrm{Xu} \mathrm{BQ}$. Engineering Pt nanoparticles with Fe and $\mathrm{N}$ codoped carbon to boost oxygen reduction catalytic performance in acidic electrolyte. Energy Technol. 2020; 8: 2000393.

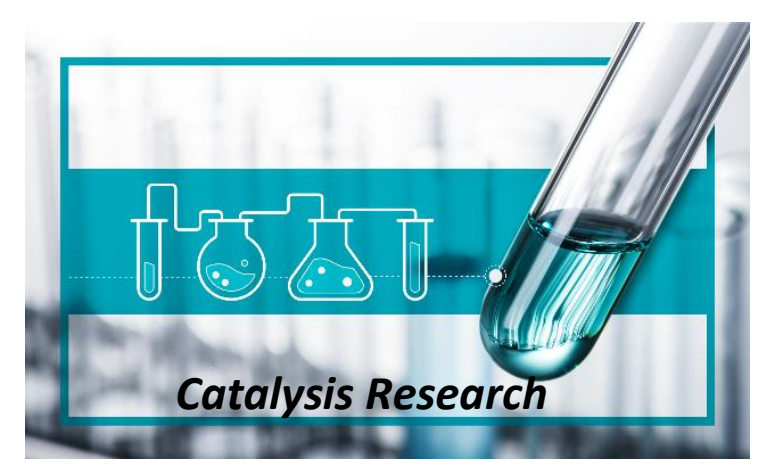

Enjoy Catalysis Research by:

1. Submitting a manuscript

2. Joining in volunteer reviewer bank

3. Joining Editorial Board

4. Guest editing a special issue

For more details, please visit: http://www.lidsen.com/journals/cr 